\title{
Depression in patients with traumatic spinal cord injuries and pressure ulcers
}

\author{
Depressão em indivíduos com lesão traumática de medula espinhal \\ com úlcera por pressão
}

\author{
Sergio Aguinaldo de \\ AlmeidA $^{1}$ \\ Patrícia Ferreira do \\ Espírito SANTO ${ }^{2}$ \\ Maiko Moura Silveira ${ }^{2}$ \\ Diego Guimarães \\ OPENHEIMER $^{3}$ \\ Rosimar Aparecida Alves \\ DUTRA $^{4}$ \\ Maria de Lourdes \\ Guarnieri Barbosa Bueno ${ }^{4}$ \\ Geraldo Magela Salome 5 \\ Maria Teresa de Jesus \\ Pereira ${ }^{6}$
}

This study was performed at the Universidade do Vale do Sapucaí (University of Vale do Sapucai UNIVAS), Pouso Alegre, MG, Brazil.

Submitted to SGP (Sistema de Gestão de Publicações/Manager Publications System) of RBCP (Revista Brasileira de Cirurgia Plástica/Brazilian Journal of Plastic Surgery).

Article received: March 16, 2013 Article accepted: April 28, 2013

\begin{abstract}
Background: Spinal cord trauma is a risk factor for the development of pressure ulcers owing to various sensory and motor changes associated with this condition. This study aimed to assess the level of depression in patients with spinal cord injuries and pressure ulcers. Methods: This was an exploratory, descriptive, and analytical study, which included 50 patients with spinal cord injuries and pressure ulcers. The data were collected between February 2010 and May 2011. In these individuals, the level of depression was assessed using the Beck Depression Inventory. Results: Among the patients, 32 (64\%) were aged between 21 and 30 years, 34 (68\%) were unemployed, 29 (58\%) were married or in stable relationship, and $31(62 \%)$ did not practice sports activities. In all, 18 (36\%) patients developed spinal injuries owing to traffic accidents and 22 (44\%) developed these owing to firearms. In all, $10(20 \%)$ patients had developed spinal cord injuries since 2 years and 9 (18\%) patients since 5 years. Category/stage III pressure ulcers were detected in $23(46 \%)$ patients, and category/stage II pressure ulcers were noted in 18 (36\%). Further, in 30 $(60 \%)$ patients, pressure ulcers were associated with the presence of exudate and odor. In all, $14(28 \%)$ patients had mild-to-moderate depression, 8 (16\%) had moderate-to-severe depression, and $3(6 \%)$ patients had severe depression. Depressive symptoms were noted in $48(96 \%)$ patients with body image issues, $31(62 \%)$ with self-deprecation, $30(60 \%)$ with social withdrawal, and $48(96 \%)$ with sleep disorders. Conclusions: Most individuals with spinal cord injuries and pressure ulcers had depression, and their main symptoms included body image issues, self-deprecation, social withdrawal, and suicidal thoughts.
\end{abstract}

Keywords: Paraplegia. Spinal cord injuries. Quality of life. Depression. Pressure ulcer.

\section{RESUMO}

Introdução: $O$ trauma raquimedular é um fator de risco para o desenvolvimento de úlcera por pressão, em decorrência das várias alterações sensitivas e motoras que o acompanham. O objetivo deste estudo foi avaliar o nível de depressão em indivíduos com lesões medulares portadores de úlcera por pressão. Método: Trata-se de estudo exploratório, descritivo e analítico, que incluiu 50 pacientes com lesão medular com úlcera por pressão. Os dados foram coletados no período compreendido entre fevereiro de 2010 e maio de 2011. Para avaliação do nível de depressão, foi utilizado o Inventário de Depressão de Beck. Resultados: Trinta e dois (64\%) pacientes tinham idade entre 21 anos e 30 anos, 34 (68\%) não tinham ocupação, 29 (58\%) eram casados ou em união estável e 31 (62\%) não praticavam atividades desportivas. Dezoito (36\%) pacientes foram vítimas de acidente de trânsito e 22 (44\%), de arma de fogo. Com relação ao tempo de lesão medular, 10 (20\%) pacientes sofreram a

1. Nurse, Audit Specialist, Sao Paulo, SP, Brazil.

2. Medical student at the Universidade do Vale do Sapucaí (University of Vale do Sapucai - UNIVAS), Pouso Alegre, MG, Brazil.

3. Physiotherapist, Professional Master Student in Applied Health Sciences at UNIVAS, Pouso Alegre, MG, Brazil.

4. Nurse, Professional Master Student in Applied Health Sciences at UNIVAS, Pouso Alegre, MG, Brazil.

5. Master, full professor and Coordinator of the Nursing Course at UNIVAS, Pouso Alegre, MG, Brazil.

6. Professor of the Professional Master's Degree in Applied Health Sciences at UNIVAS, Pouso Alegre, MG, Brazil. 
lesão havia 2 anos e 9 (18\%), 5 anos. Quanto à categoria/estágio da úlcera por pressão, 23 (46\%) pacientes eram da categoria/estágio III e 18 (36\%), da categoria/estágio II. Trinta $(60 \%)$ pacientes apresentavam úlceras por pressão com presença de exsudato e odor. No que se refere ao nível de depressão, 14 (28\%) dos pacientes apresentaram depressão considerada leve a moderada, $8(16 \%)$, depressão moderada a grave e $3(6 \%)$, depressão grave. No que concerne aos sintomas de depressão, 48 (96\%) pacientes apresentaram distorção da imagem corporal, 31 (62\%), autodepreciação, 30 (60\%), retração social e 48 (96\%), distúrbio do sono. Conclusões: A maioria dos indivíduos com lesão medular com úlcera por pressão apresentou depressão, tendo como principais sintomas: distorção da imagem corporal, autodepreciação, retração social e ideia suicida.

Descritores: Paraplegia. Traumatismos da medula espinal. Qualidade de vida. Depressão. Úlcera por pressão.

\section{INTRODUCTION}

The number of spinal cord injuries is increasing mainly owing to increased incidences of urban violence. Traffic accidents and gunshot wounds are the leading causes of spinal cord trauma. Damage to the spinal cord causes motor, sensory, and autonomous changes that cause partial or total loss of voluntary movements or sensitivity (tactile, painful, and deep) of the upper and/or lower limbs, as well as changes in the efficiency of the urinary, intestinal, respiratory, circulatory, and reproductive systems ${ }^{1}$.

Spinal cord trauma is a risk factor for the development of pressure ulcers owing to various sensory and motor changes that are associated with this condition. However, we assume that patients with paraplegia can care for themselves in an easier and more independent manner ${ }^{2}$.

Patients with pressure ulcers experience increased physical and emotional suffering, increased hospitalizations, and reduced self-esteem that may influence their self-image and quality of life, which then leads to exacerbate depression. Therefore, these patients deserve attention from a multidisciplinary team to prevent the occurrence of depression or facilitate its treatment ${ }^{3}$.

Spinal cord injuries are severe and irreversible, and patients with these injuries require to undergo a long-term rehabilitation program that does not cure, but facilitates their process of adaptation to a new life in most cases. The sequelae and difficulties faced by these patients in returning to their family life, performing leisure activities, and participating in social life impair their quality of life. Therefore, care required by these patients is a challenge to professionals involved in the rehabilitation program ${ }^{4-7}$.

Depression is one of the ten leading global causes of disability, because it limits the physical, personal, and social activities, and it can affect anyone, anytime, and at any age. Depression often interferes with daily life activates and affects those living with the depressed patient ${ }^{8}$.
People with depression are often stigmatized by society, and only a few receive proper treatment. The way symptoms of depression are identified in patients, and theories related to etiology can influence their willingness to seek help and agree to treatment, as well as influence the attitude and behavior of the community towards them ${ }^{9}$.

Given the importance of depression, this study aimed to contribute to further understanding of the disorder and help in the development of a care plan suited to depressed patients with spinal cord injury and pressure ulcers.

The study aimed to assess depression in individuals with spinal cord injuries and pressure ulcers.

\section{METHODS}

This is an exploratory, descriptive, and analytical study, which included 50 patients with spinal cord injury and pressure ulcers.

In this study, we included 50 adult, conscious, and oriented patients with lumbar and dorsal spinal cord injuries, who were being treated at the outpatient stoma therapy, medical, surgical, and orthopedic clinics of the Hospital Complex of Sorocaba in Brazil.

This study was performed between February 2010 and May 2011, and we received approval from the Research Ethics Committee of the Federal University of Sao Paulo, 0032/2010.

We excluded patients presenting with a cervical lesion who had no pressure ulcers.

We collected data on sociodemographic status, spinal cord injury, and pressure ulcers. The Beck Depression Inventory, which was developed in the sixties and translated into Portuguese and validated in Brazil, was used to assess depression. The inventory has 21 categories of symptoms and behaviors typical of depression, which include vegetative, social, and cognitive symptoms as well as measures of humor and irritability ${ }^{9,10}$. Each category consists of a series of four 
different scores of intensity per manifestation ( 0 to 3 points), with a total of 63 points.

In this study, we classified Beckmann scores for less than 9 as corresponding to no or mild depression, scores of 10 to 18 as mild-to-moderate depression, scores of 19 to 29 as moderate-to-severe depression, and scores of 30 to 63 as severe depression ${ }^{10}$.

Student's t-test and Chi-square independence test $(\mathrm{p}<0.05)$ were used for statistical analysis.

\section{RESULTS}

Among the 50 patients evaluated, $40(80 \%)$ were men, $32(64 \%)$ were aged between 21 and 30 years, $34(68 \%)$ were unemployed, $29(58 \%)$ were married or in a stable relationship, and $31(62 \%)$ did not practice sports activities (Table 1).

Causes of spinal injury were traffic accidents in 18 (36\%) patients and gunshots in $22(44 \%)$ patients. A lumbar spinal cord injury occurred in 26 (52\%) patients (Table 2). Ten $(20 \%)$ patients had spinal injury since 2 years of age, and 9
(18\%) patients had spinal injury since they were 5 . All of the patients presented with neurogenic-related bowel or bladder complications of their spinal injury. Pressure ulcers of category/stage III were detected in $23(46 \%)$ patients, and those of category/stage II were detected in $18(36 \%)$ patients. In $30(60 \%)$ of the patients, the pressure ulcers were associated with the presence of exudate and odor.

Table 3 shows that $25(50 \%)$ patients did not show any signs of depression, and 14 (28\%) were classified as having mild-to-moderate depression. Table 4 shows that $48(96 \%)$ patients presented with body image distortion as a symptom of their depression, 48 (96\%) had suicidal thoughts, while $31(62 \%)$ had self-deprecation and $30(60 \%)$ had social withdrawal.

\section{DISCUSSION}

The number of spinal cord injuries has significantly increased in recent years, and this number correlates with the level of development of a country. The etiology is predominantly associated with motor vehicle accidents and mainly

\begin{tabular}{|c|c|c|c|c|c|}
\hline Gender & $\mathbf{N}$ & $\%$ & $\%$ Valid & $\%$ Accumulated & $\mathbf{P}$ \\
\hline Male & 40 & 80 & 80 & 80 & \\
\hline Female & 10 & 20 & 20 & 100 & 0.001 \\
\hline Total & 50 & 100 & 100 & & \\
\hline Marital status & $\mathbf{N}$ & $\%$ & $\%$ Valid & $\%$ Accumulated & $\mathbf{P}$ \\
\hline Single & 21 & 42 & 42 & 42 & \\
\hline Married or in stable union & 29 & 58 & 58 & 100 & 0.002 \\
\hline Total & 50 & 100 & & & \\
\hline Age & $\mathbf{N}$ & $\%$ & $\%$ Valid & $\%$ Accumulated & $\mathbf{P}$ \\
\hline$<20$ & 4 & 8 & 8 & 8 & \\
\hline $21-30$ & 32 & 64 & 64 & 64 & \\
\hline $31-40$ & 6 & 12 & 12 & 12 & 0.002 \\
\hline $41-50$ & 5 & 10 & 10 & 10 & \\
\hline $51-60$ & 3 & 6 & 6 & 100 & \\
\hline Total & 50 & 100 & & & \\
\hline Profession & $\mathbf{N}$ & $\%$ & $\%$ Valid & \% Accumulated & \\
\hline Retired & 4 & 8 & 8 & 8 & \\
\hline Employed & 12 & 24 & 24 & 24 & 0.001 \\
\hline Unemployed & 34 & 68 & 68 & 100 & \\
\hline Total & $\mathbf{5 0}$ & 100 & 100 & & \\
\hline Sport activities & $\mathbf{N}$ & $\%$ & $\%$ Valid & $\%$ Accumulated & \\
\hline Yes & 19 & 38 & 38 & 38 & \\
\hline No & 31 & 62 & 62 & 100 & 0.0001 \\
\hline Total & 50 & 100 & 100 & & \\
\hline
\end{tabular}




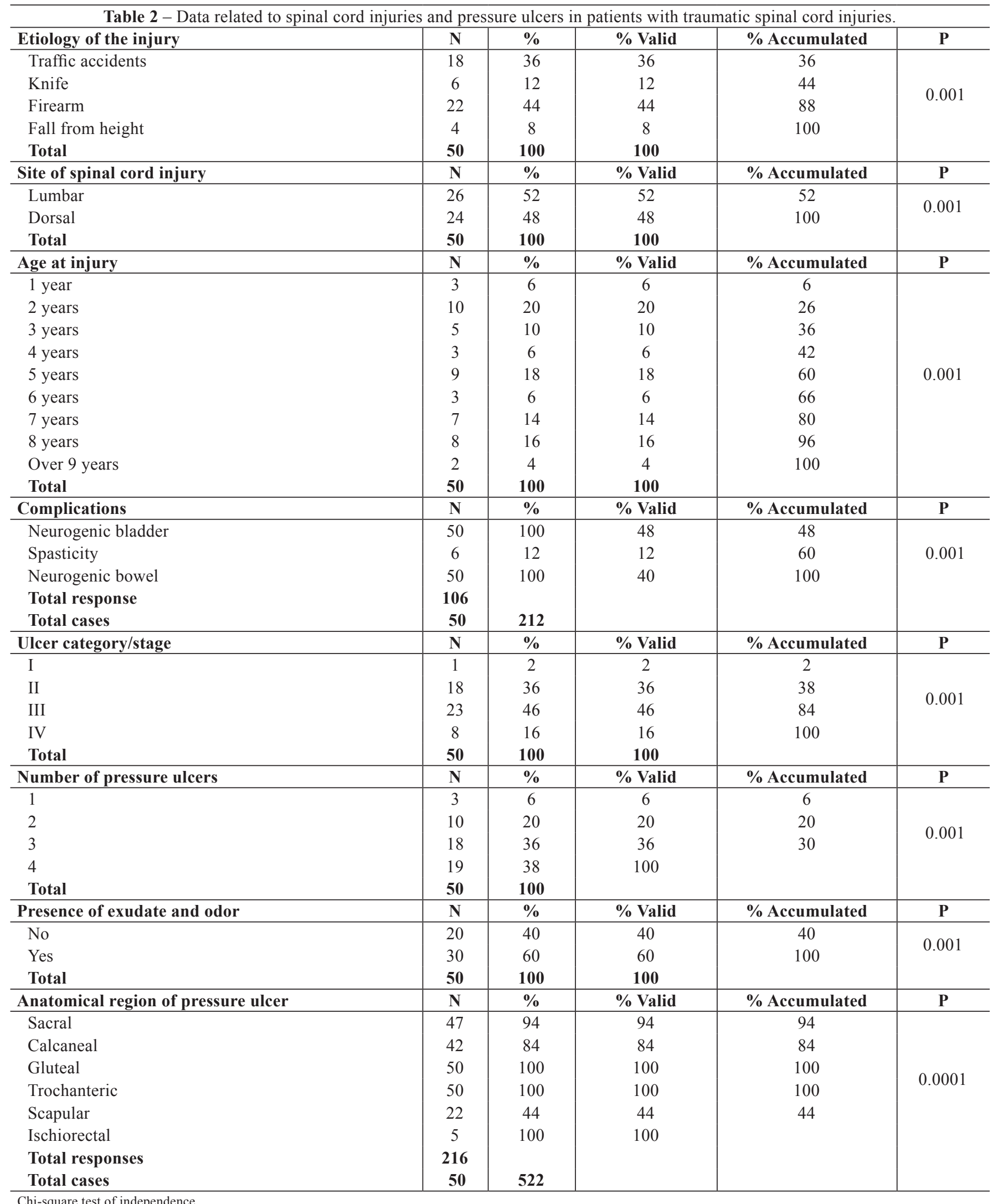


Table 3 - Classification of the symptoms of depression using the Beck Depression Inventory in individuals with spinal cord injuries and pressure ulcers.

\begin{tabular}{l|c|c|c|c|c}
\hline Level of depression & $\mathbf{N}$ & $\mathbf{\%}$ & $\mathbf{\%}$ Valid & \% Accumulated & P \\
\hline None or minimal & 25 & 50 & 50 & 50 & 78 \\
\hline Mild to moderate & 14 & 28 & 28 & 94 & 0.001 \\
\hline Moderate to severe & 8 & 16 & 16 & 100 & \\
\hline Severe & 3 & 6 & $\mathbf{1 0 0}$ & & \\
\hline Total & $\mathbf{5 0}$ & $\mathbf{1 0 0}$ & $\mathbf{1 0 0}$ & \\
\hline
\end{tabular}

Student's t-test and Chi-square test of independence.

Table 4 - Responses to the Beck Depression Inventory for depressive symptoms in patients with spinal cord injuries and pressure ulcers.

\begin{tabular}{l|c|c}
\hline \multirow{2}{*}{ Depressive symptoms } & \multicolumn{2}{|c}{ Response } \\
\cline { 2 - 3 } & $\mathbf{N}$ & $\mathbf{\%}$ \\
\hline Body image distortion & 48 & 96 \\
\hline Suicidal idea & 48 & 96 \\
\hline Self-deprecation & 31 & 62 \\
\hline Social withdrawal & 30 & 60 \\
\hline Lack of satisfaction & 24 & 48 \\
\hline Pessimism & 18 & 36 \\
\hline Work inhibition & 18 & 36 \\
\hline Sense of failure & 14 & 28 \\
\hline Irritability & 11 & 22 \\
\hline Decreased libido & 10 & 20 \\
\hline Crying crises & 9 & 18 \\
\hline Indecision & 7 & 14 \\
\hline Somatic concern & 6 & 12 \\
\hline Appetite loss & 4 & 8 \\
\hline Weight loss & 2 & 4 \\
\hline Punishment feeling & 2 & 4 \\
\hline Sleep disorder & 2 & 4 \\
\hline Guilt feeling & 2 & 4 \\
\hline Fatigue & $\mathbf{2 4 1}$ & 2 \\
\hline Total responses & & 482 \\
\hline Total cases & 1 & \\
\hline & & \\
\hline & 10 & 2 \\
\hline
\end{tabular}

involves teenagers and men ${ }^{11}$. The occurrence of spinal injury is rapid and unexpected, is a frightening experience for the patient, and impacts all aspects of their lives, as well as causes changes in their bodies.

The demographic characteristics of most patients in this study included male gender, age between 21 and 30 years, being unemployed, married or in stable relationships, and did not practice sports. Our results were similar to those of other national and international studies ${ }^{12-14}$.
The advantages of practicing sports in patients with spinal cord injuries include improved oxygen consumption $\left(\mathrm{VO}_{2} \mathrm{max}\right)$, gain in aerobic capacity, reduced risk of cardiovascular diseases and respiratory infections, decreased incidence of medical complications of spinal injury (infections of the urinary tract and the kidney and bedsores), reduced hospitalizations, increased life expectancy, and community integration, support in coping with disability, independence, improved self-image and self-esteem, life satisfaction, and a reduced risk of psychological disorders ${ }^{15,16}$.

Several studies suggest that regular physical activity is associated with increased functional status and improved quality of life in those with disability; it protects against disease by promoting health and maintaining functional independence $^{17,18}$.

Most study patients developed spinal cord injuries owing to traffic accidents, followed by firearm injuries. This finding correlates with the findings in studies on the etiology of this condition $^{13,17,18}$. In Brazil, 130 thousands individuals suffer from spinal cord injury. The annual increase in its incidence is due to increased urbanization throughout the country ${ }^{13}$.

The symptoms and complications of spinal cord injuries depend on the extent and location of the injury and the time at which it occurred; differences in these aspects may lead to variations in the physiological functions induced by respiratory, vascular, urinary, intestinal, and musculoskeletal damage, as well as pressure ulcers ${ }^{1,19}$.

In addition to sensory and motor damage, spinal cord injury alters the function of the excretory system with the loss of bladder and anal sphincter control. The inability to control the bladder sphincter often causes lack of social acceptance, prevents complete rehabilitation, and causes clinical complications, such as urinary infections, vesicular lithiasis, and hydronephrosis, and various excretory problems (fecal incontinence, constipation, and patient discomfort) in addition to other neurogenic disorders ${ }^{12}$.

In this study, $46 \%$ of the patients had category/stage III pressure ulcers and $36 \%$ had category/stage II pressure ulcers, which correlated with the findings of other national and international studies ${ }^{20-22}$. 
Pressure ulcers are a serious and frequent complication in patients with spinal cord injuries, which directly or indirectly interfere with their quality of life. If stage III and IV ulcers occur, wound healing often requires frequent visits to the health services (outpatient clinics, hospitals, clinics, or home treatment assisted by competent professionals) for curative or reparative procedures ${ }^{23,24}$.

Spinal cord injury is a high burden because such patients have to face new problems of physical activity and locomotion that force them to change and adapt to different roles and approaches for activities they could perform before their injury. This injury results in loss of independence, social isolation, reduced quality of life, affects self-esteem and self-image, and function, and is associated with increased anxiety and depression ${ }^{11,25,26}$.

Spinal cord injury causes physical, psychological, and social disabilities in individuals and is considered the most serious and devastating disability in humans, which affects their functions, including locomotion ${ }^{27}$.

The debilitating consequences of spinal cord injury include impaired ability to perform daily activities, limiting mobility and social involvement ${ }^{28}$.

These physical changes are social barriers, which hamper the life of patients with spinal cord injuries and interfere with their self-esteem and quality of life.

In a study by Bampi et al. ${ }^{29}$ that included 35 patients with spinal cord injuries, the World Health Organization Quality of Life (WHOQOL) instrument was used to assess physical, psychological, and social relationships as well as the environment. A significant reduction in quality of life was seen in patients, and the physical, psychological, and environmental domains of these patients were significantly affected. The authors concluded that the physical aspect was the most affected. The evidence supported that the psychological and environmental domains of such patients are significantly different from those of the general population ${ }^{29}$.

Cassano assessed the perception of quality of life using the WHOQOL-bref (shorter version of WHOQOL) instrument in 111 patients with traumatic spinal cord injury. In terms of quality of life, domains that had low scores were related to the environment and physical health. In contrast, higher scores were found to be associated to psychological health and social relationships ${ }^{30}$.

Other evidence suggests that depression and quality of life are different concepts, and reducing symptoms of depression does not necessarily improve quality of life. In dysthymic patients, symptom relief improves social and occupational functioning. However, leisure activities in such patients may not remain enjoyable ${ }^{31}$.

In a review article, Salomé et al. ${ }^{32}$ suggested that the presence of depressive symptoms significantly impacts patients' quality of life, and the impact is not restricted only to the clinical features of this disorder. Therefore, assessment of quality of life with multi-dimensional factors is relevant, and it will detect the magnitude and extent of the impairment caused by depression ${ }^{32}$.

Typical symptoms involve somatic alterations, which affect mood, motivation, and concentration and cause sadness, pessimism, low self-esteem, anxiety, and suicidal behavior $^{32,33}$.

This study highlights the necessity to redirect attention to spinal cord injury patients' mental health. Health care services should aim to identify the impact of changes in the quality of life, self-esteem and self-image, anxiety and depression in patients with spinal cord injury and pressure ulcers. Special attention should be paid to the needs of individual patients and the knowledge that caregivers need acquire to deal with disabilities. Future multicenter comparative studies should be performed with larger sample sizes in order to fully understand the magnitude of the effect of this condition on patients.

\section{CONCLUSIONS}

In this study, we found that half of the patients with spinal cord injury and pressure ulcers present with mild-tomoderate to moderate-to-severe symptoms of depression. The most common symptoms noted in our study were body image issues, self-deprecation, social withdrawal, and suicidal thoughts.

\section{REFERENCES}

1. Ackery A, Tator C, Krassioukov A. A global perspective on spinal cord injury epidemiology. J Neurotrauma. 2004;21(10):1355-70.

2. New PW, Rawicki HB, Bailey MJ. Nontraumatic spinal cord injury rehabilitation: pressure ulcer patterns, prediction, and impact. Arch Phys Med Rehabil. 2004;85(1):87-93.

3. Blanes L, Duarte IS, Ferreira LM. Avaliação clínica e epidemiológica das úlceras por pressão em pacientes internados no Hospital São Paulo. Rev Assoc Med Bras. 2004;50(2):182-7.

4. Ramírez-Maestre C, Esteve R, López AE. The role of optimism and pessimism in chronic pain patients adjustment. Span J Psychol. 2012; 15(1):286-94

5. Vall J, Braa VAB, Almeida PC. Estudo da qualidade de vida em pessoas com lesão medular traumática. Arq Neuropsiquiatr. 2006;64(2-b): 451-5.

6. Blanes L, Carmagnani MI, Ferreira LM. Quality of life and self-esteem of persons with paraplegia living in São Paulo, Brazil. Qual Life Res. 2009; 18(1):15-21.

7. Carvalho Z. O significado da paraplegia para pacientes internados: implicações para cuidados e enfermagem. Rev Pensar Enferm. 2002; 6(2):16-24.

8. Işıntaş M, Ak M, Erdem M, Oz O, Ozgen F. Event-related potentials in major depressive disorder: the relationship between P300 and treatment response. Turk Psikiyatri Derg. 2012;23(1):33-9.

9. Gorenstem C, Andrade LHSG. Inventário de depressão de Beck: propriedades psicométrica da versão em português. Rev Psiquiatr Clín. 1998;25(5):245-50

10. Beck AT, Ward CH, Mendelson M, Mock J, Erbaugh J. An inventory for measuring depression. Arch Gen Psychiatry. 1961;4:561-71. 
11. Amaral MTMP. Encontrar um novo sentido da vida: um estudo explicativo da adaptação após lesão medular. Rev Esc Enferm USP. 2009; 43(3):573-80.

12. Padula MPC, Souza MF. Effect of an educational program in intestinal elimination self-care deficits among individuals with paraplegia. Acta Paul Enferm. 2007;20(2):168-74.

13. Blanes L, Lourenço L, Carmagnani MI, Ferreira LM. Clinical and socio-demographic characteristic of persons with traumatic paraplegia living in São Paulo. Arq Neuropsiquiatr. 2009;67(2B):388-90.

14. Studart RMB, Melo EM, Lopes MVO, Barbosa IV, Carvalho ZMF. Tecnologia de enfermagem na prevenção da úlcera por pressão em pessoas com lesão medular. Rev Bras Enferm. 2011;64(3):494-500.

15. Salomé GM, Pellegrino DMS, Blanes L, Ferreira LM. Self-esteem in patients with diabetes mellitus and foot ulcers. J Tissue Viability. 2011;20(3):100-6.

16. Silva MCR, Oliveira RJ, Conceição MIG. Efeitos da natação sobre a independência funcional de pacientes com lesão medular. Rev Bras Med Esporte. 2005;11(4):251-6.

17. Melo ACR. Descrição da aptidão inicial para natação em lesionados medulares. Rev Bras Med Esporte. 2009;15(6):441-5.

18. Brito LMO, Chein MBC, Marinho SC, Duarte TB. Avaliação epidemiológica dos pacientes vítimas de traumatismo raquimedular. Rev Col Bras Cir. 2011;38(5):304-9.

19. Figueiredo ZM, Tirado JJ, Mulet FV, Núñez AJ, Andrade LM, Miranda MC, et al. Úlceras por pressão em pessoas com lesão medular: conhecimento de familiares e cuidadores. Av Enferm. 2010;28(n. esp.):29-38.

20. Leite VBE, Faro ACM. Identificação de fatores associados às úlceras por pressão em indivíduos paraplégicos relacionados às atividades de lazer. Acta Fisiatr. 2006;13(1):21-5.

21. Nogueira PC, Caliri MHL, Haas VJ. Perfil de pacientes com lesão traumática da medula espinhal e ocorrência de úlcera de pressão em um hospital universitário. Rev Lat Am Enfermagem. 2006;14(3):372-7.

22. Idowu OK, Yinusa W, Gbadegesin SA, Adebule GT. Risk factors for pressure ulceration in a resource constrained spinal injury service. Spinal Cord. 2011;49(5):643-7.
23. Salomé GM. Incidência e fatores de risco para úlcera por pressão em um conjunto hospitalar. Nursing. 2011;14(160):491-5.

24. Gonçalves AMT, Rosa LN, D’Ângelo CT, Savordelli CL, Bonin GL, Squarcino IM, et al. Aspectos epidemiológicos da lesão medular traumática na área de referência do Hospital Estadual Mário Covas. Arq Med ABC. 2007;32(2):64-6.

25. Saadat S, Javadi M, Divshali BS, Tavakoli AH, Ghodsi SM, Montazeri A, et al. Health-related quality of life among individuals with longstanding spinal cord injury: a comparative study of veterans and nonveterans. BMC Public Health. 2010;10:6.

26. Sánchez Raia J, Romero Culleres G, González Viejo MA, Ramírez Garcerán L, García Fernández L, Conejero Sugrañes J. Quality of life evaluation in spinal cord injured patients comparing different bladder management techniques. Actas Urol Esp. 2010;34(6):537-42.

27. MuttiCG. Avaliação das diferenças funcionais entre pacientes paraplégicos por trauma raquimedular que frequentaram e que não frequentaram um centro de reabilitação [dissertação]. São Paulo: Universidade de São Paulo; 2008.

28. Ball CG, Navsaria P, Kirkpatrick AW, Vercler C, Dixon E, Zink J, et al. The impact of country and culture on end-of-life care for injured patients: results from an international survey. J Trauma. 2010;69(6): 1323-33.

29. Bampi LNS, Guilhem D, Lima DD. Qualidade de vida em pessoas com lesão medular traumática: um estudo com o WHOQOL-bref. Rev Bras Epidemiol. 2008;11(1):67-77.

30. Cassano GB. Social adjustment in dysthymia. In: Burton SW, Akiskal HS, ed. Dysthymic disorder. London: Gaskell; 1990. p. 78-85.

31. Lima AFBS, Fleck MPA. Qualidade de vida e depressão: uma revisão da literatura. Rev Psiquiatr Rio Gd Sul. 2009;31(3 Suppl).

32. Moraes MH, Silva EM, Francini Neto GSS, Rabello JK, Guerra LJ. Depressão e suicídio no filme "As Horas". Rev Psiquiatr Rio Gd Sul. 2006;28(1):83-92.

33. Salomé GM, Blanes L, Ferreira LM. Assessment of depressive symptoms in people with diabetes mellitus and foot ulcers. Rev Col Bras Cir. 2011; $38(5): 327-33$

\section{Correspondence to:}

Sérgio Aguinaldo de Almeida

Av. Francisco de Paula Quintaninha Ribeiro, 280 - ap. 134 - bloco 1 - Jabaquara - São Paulo, SP, Brazil CEP 04330-020

E-mail: estomaterapeuta@outlook.com 